\title{
Sixth-grade students' experiences of a digital game-based learning environment: A didactic analysis
}

\author{
Mustafa Gök ${ }^{1^{*}}$, Mevlüt İnan² \\ ${ }^{1}$ Faculty of Education, Van Yuzuncu Yil University, Turkey \\ ${ }^{2}$ Department of Computer Programming, Van Yuzuncu Yil University, Turkey \\ *Corresponding author: mustafagok@yyu.edu.tr
}

\begin{tabular}{l} 
ARTICLE INFO \\
\hline Article history: \\
Received: 14 February 2021 \\
Revised: 19 March 2021 \\
Accepted: 24 March 2021 \\
Published online: 1 April 2021 \\
Published regularly: April \\
2021
\end{tabular}

ABSTRACT

Students' conceptual understanding and mathematical process skills can be improved through digital games in mathematics education. The starting point of this study is the idea of having students encounters this kind of environment. The study didactically describes the process of 6 thgrade students' experiences of a digital game-based learning environment. A combination of the Theory of Didactical Situations (TDS) and Digital Game-Based Learning (DGBL) was used in the design of the digital game. The research focused on knowledge-based interactions (teacher-studentgame) during the implementation of the game called Race with Numbers, designed in line with this synthesis. The case study, one of the qualitative research methods, was used in the study. Research participants consist of 16 middle secondary school students studying in

Keywords:

Theory of didactical situations, game-based learning, $6^{\text {th }}$ grade, constructivism, mathematical process skills the 6th grade in a public school. The research data were collected with a video camera and two voice recorders. The research application lasted 75 minutes. The data analysis related to the application was carried out by describing the interaction between the students and the game at stages of TDS. The study findings indicated that TDS has significant potential in designing DGBL environments. However, strong evidence is presented that such environments enable students to realize their own learning and encourage them to use mathematical process skills (such as problemsolving, reasoning, proving, and transfer). Finally, the study highlights the importance of the digital game-based learning approach in mathematics teaching for students.

(C) 2021 Universitas Muhammadiyah Surakarta

\section{Introduction}

Today, the idea of taking advantage of technological developments profoundly affects the practices people are accustomed to in all areas (Macfarlane, 2020). This causes the use of alternative approaches in teaching environments in many disciplines of education (Lowrie \& Jorgensen, 2015). One of the disciplines is mathematics education.

There can be many factors in the use of technology in mathematics education. The nature of mathematical knowledge is one of them. Mathematical knowledge is abstract as it reflects the general situation (Dahl, 2018). Technology is often used to understand 
mathematical knowledge or design environments that reveal its meaning (Radović, Marić, \& Passey, 2019). Thus, it is emphasized that technology can be an effective tool in mathematics education (The National Council of Teachers of Mathematics [NCTM], 2000; Cullen, Hertel, \& Nickels, 2020). However, to what extent the use of technology alone in teaching environments is sustainable for today's generation is still debated.

Although learning environments where only technological tools are used seem attractive at first, it is stated that the learning experiences that are to be presented to a generation that has been surrounded by technology and centered on technology since birth is not sustainable (Iivari, Sharma, \& Ventä-Olkkonen, 2020). An effective way to make technology integration into the learning environment sustainable is digital game-based learning (DGBL), in which games are used as learning tools (Kiili, 2005; Van Eck, 2006).

\section{The use of DGBL in mathematics education}

Research designed in the context of DGBL has been popular in the academic literature in recent years. The main reason for this is that the knowledge is presented to the students in a fun atmosphere designed. Pointing to this fact, Prensky (2001) emphasized that the main feature of DGBL environments is the integration of serious learning and interactive entertainment.

Digital games were found to not only make learning fun but also enable focusing on the task (Chen, Liao, Cheng, Yeh, \& Chan, 2012), motivate learning and increase success (Hung, Huang, \& Hwang, 2014), and affect performance and attitude (Ke \& Grabowski, 2007). These results imply that digital games should not be designed randomly for educational goals and should include certain features. However, it is seen that researchers disagree on the features that should be found in a digital game that will serve educational purposes.

Mayer and Johnson (ㅁ10) stated that an educational computer game should have four features: rule-based, responsive, challenging, and cumulative. Prensky (2001) explained these characteristics as follows: 1) rules, 2) goals and objectives, 3) outcomes and feedback, 4) challenge, 5) interaction, and 6) representation or story.

How can these game features be integrated into mathematics education? In answer to this question, Yong, Karjanto, Gates, Chan, and Khin (ㅁ2020) proposed four criteria for game integration into mathematics education: 1) problem-based learning, 2) process-oriented learning, 3) turning mistakes into opportunities, and 4) stories. In another study, it is stated that such a digital game should include initial strategies, reflection, and abstraction (Jong, Shang, Lee, \& Lee, 2008). It can be assumed that the well-known emphasis in these studies is to make students experience mathematical processes. In this context, mathematical processes are explained as trial and error, hypothesis assertion, hypothesis testing, proofing, problem-solving, reasoning and proving, conveying (sharing), relating, and representing (Arsac, Germain, \& Mante, 1991; NCTM, 2000).

Learning theories about how mathematical processes can be used regarding how digital games should take place in learning environments. Yong et al. (2020) stated that learning theories (such as experimental learning and constructivist theories) provide a foundation for understanding how students learn in a game designed within the scope of DGBL. Emphasizing this fact, Gee (2007) argued that it is more appropriate for today's students to experience learning theories through reflections in a good digital game rather than situations they are taught at school. Therefore, in this study, the students were provided to experience a suitable learning environment by using the relationship between TDS and DGBL. 


\section{The Potential of the Theory of Didactical Situations Regarding DGBL}

The Theory of Didactical Situations (TDS) (Brousseau, 2002), a game-based theory, offers solid arguments for students' acquisition of knowledge through a carefully designed game tool. The theory adopts knowledge acquisition in a student-centered environment (Laborde, 2007). Similarly, a learning environment in DGBL is created in which students can act independently in a game designed with a balanced integration of educational content (e.g., mathematical knowledge) and game components. Based on this, it can be stated that the arguments of the theory offer a suitable atmosphere for DGBL.

In theory, the concept of the situation has central importance. The situation is the relevant conditions that require one or more students to use and learn mathematical knowledge or a project organized correctly in this context (Warfield, 2014; Brousseau \& Warfield, 2014). It is the milieu that students have to struggle with in a didactic situation. The milieu is all the relevant characteristics of the student's surroundings, including area, teacher, materials, and presence or absence of other students (Warfield, 2014). In this regard, the milieu functions as modeling the gamers' or students' activities within certain cognitive, social, and physical elements (e.g., prior knowledge, group interaction, a data set, a special technology) (Nickels \& Cullen, 2017). Since the aim is to achieve an instructional goal, the milieu should be carefully designed. Thus, digital games can be used effectively in creating these conditions.

In a digital game, mathematical knowledge can be hidden because of being surrounded by the game features. In this way, the problem situation consisting of many tasks caused by some constraints and conditions can be presented to students implicitly in a digital game (Gök, İnan, \& Akbayır, 2020). Such learning are within the scope of a didactic situations (Brousseau, 2002), as the intervention of the authority (e.g., teacher) is limited, the knowledge is hidden from the students for a while, and they are organized in a way that allows themto act independently during the game process. Each didactic process has three stages: devolution stage, mathematical stage (action, formulation, and validation), and institutionalization stage (Brousseau \& Warfield, 2014).

The devolution stage is the students taking responsibility for what they will do without getting any help from the authority, after the criteria, such as the conditions, rules, purpose, success in the game, which are necessary to create an interesting and instructive mathematical situation (e.g., using a digital game), are explained by the authority.

In the mathematical stage, students should experience the environment and produce new things (such as knowledge, expressions) from the feedback they get from the game, and discuss their validity first in the group and then, with the participation of the whole class, make decisions in this direction, and form hypotheses and try to prove them. They should also generate models, arguments, and proofs from the assured conclusions and organize them to achieve a more general goal. Moreover, they should evaluate and correct the results of their choices on their own in this stage.

Finally, in the institutionalization stage, the authority notes students' responses to the problem presented in the context of the game in the mathematical situation and their progress in the problem, placing them in the perspective of the curriculum. In other words, this stage provides a standard way of formulating or generalizing the pieces of knowledge that students somehow discover in the process of the game.

These stages allow students to experience different mathematical processes. Since teacher intervention is limited, especially in the mathematical stage, it is thought that students can use many mathematical processes in interaction with objects as the source of 
knowledge (such as inferences in the context of the game) and with one another. Students use mathematical processes effectively in the situations mentioned (Brousseau, 2002). For instance, Brousseau (2002) expressed that students can use pragmatic, semantic, and intellectual reasons in the mathematical stage. If an argument is uncovered through trial and error, it is for pragmatic reasons. It is semantic reasons if it is presented concerning a previously played game. It is intellectual reasons if it is based on logical inference.

A concept called didactic contract is used in theory for the successful functioning of these processes. On the basis of knowledge, the didactic contract is the sum of the expectations of teachers and students from each other (Brousseau, 2002; Warfield, 2014). This contract, usually based on implicit rules, occurs in negative situations such as a student not wanting to solve a problem. More clearly, this concept is necessary for students to take the responsibility of solving it implicitly presented in the game and to move forward in the game by acting independently on the basis of knowledge.

Although TDS has a great potential in digital game design, it is seen that there are very few studies in this framework in the literature (Gök et al., 2020; Nickels \& Cullen, 2017). Nickels and Cullen (2017) underlined that robotic games designed within the framework of a didactic conditions for a 14-year-old child with a critical illness (Acute Lymphoblastic Leukemia) provide strong evidence for performing robotic tasks designed in this context. Another study was carried out with pre-service teachers (Gök et al., 2020), and there is no study in the literature in which mathematical knowledge is taught to middle school students in a didactical situation by designing a digital game.

This study describes the process of experiencing a digital game designed by a didactical situation of 6th-grade students at different stages of TDS. The unique value of the study is how a digital game that reflects the meaning of mathematical knowledge and the a didactical situation, enables students to use their mathematical process skills.

\section{Research Methods}

This study reveals the 6th-grade students' experience process of DGBL designed with a didactic perspective. Since they experience a learning environment related to DGBL for the first time in the context of this learning environment's limitations, the case study (Merriam, 2013) provides appropriate tools for such an experience process.

The analysis process regarding how the case study is conducted plays a fundamental role. In this study, the analysis process constitutes the students' actions based on knowledge within the context of TDS with regards to DGBL. The study's focus is on what they experience in the stages of TDS and how they perform the mathematical processes to access the knowledge behind the designed game.

The knowledge behind the game designed in this study is based on a course objective included in the students' elementary school mathematics curriculum, and it is not taught by the teacher. The game was designed in a way to provide an effective warm-up to start teaching this objective. The designed digital game does not necessarily reflect all aspects of the objective, as it is considered a warm-up activity. Behind the digital game designed in the perspective of mathematical knowledge is the Euclidean division.

\section{Participants}

The research participants consisted of 16 (7 girls and 9 boys) students studying in the 6th grade of a public school in Turkey's Eastern Anatolia region. After oral permission was obtained from the school administration, the study was carried out with the voluntary participation of 16 students from the class of 34 . 
The mathematics teacher of these students stated that they previously did not have a learning experience in the context of DGBL. On the other hand, according to the teacher's statement, the students' socio-economic status is moderate, and they have good skills in using technology, and they are usually accustomed to playing different games.

\section{Game and Application Process}

Race with Numbers game is a variation of the Race to 20 game, in which Brousseau (2002) introduced the main arguments of TDS. A digital game was developed by expanding the game Race to 20 to a certain extent and adapting it in a different context (balloon popping). Since this game aims not only to play the game but also to discover the mathematical knowledge hidden beyond the game (Prensky, 2001), it can be evaluated in the context of DGBL. In the study, permission was obtained to use the game developed within the scope of a project (Gök et al., 2020).

\section{Race with Numbers}

Race with Numbers is a game in which players play against the computer and face winning or losing position at the end of the game. The winning numbers in the game form a changing number sequence for each task. The game consists of easy, medium, and hard levels, and they are organized according to when the computer activates the winning number sequence in the game. For example, the computer activates a sequence of winning numbers in moves near the end of the game at the easy level. In contrast, the algorithm is activated in the first moments of the game at the hard level. Each level consists of 12 tasks.

Each task has a certain number of balloons on the game screen (for example, 16 in the first mission, 18 in the second, and 20 in the third). Those that players can choose are in red, and these balloons are activated in two, three, and four each in tasks. The balloons chosen by the player are colored green, balloons selected by the computer are colored orange, and balloons that are not selected are marked light gray. 1, 2, ..,n numbers are written in the center of the balloons, allowing easier monitoring of the process, giving different strategies, and better discussion of strategies. The goal of the game is to reach the largest numbered balloon on the screen. Figure 1 shows the screenshots of the digital game.

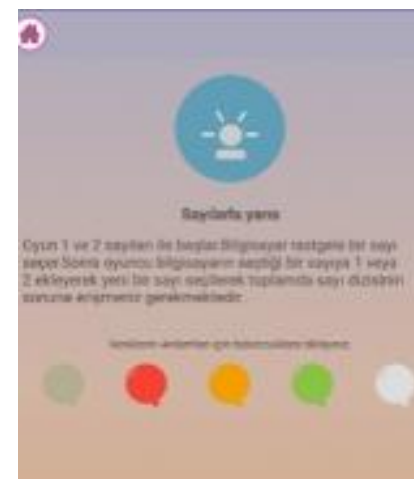

Introduction

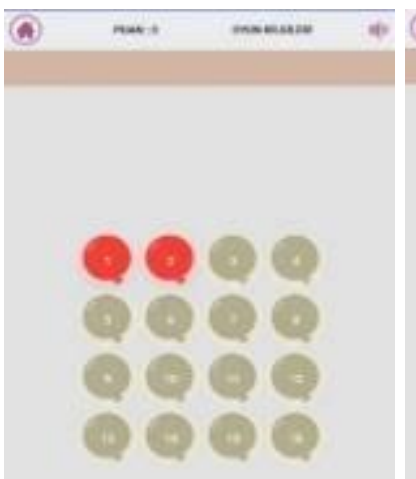

Starting

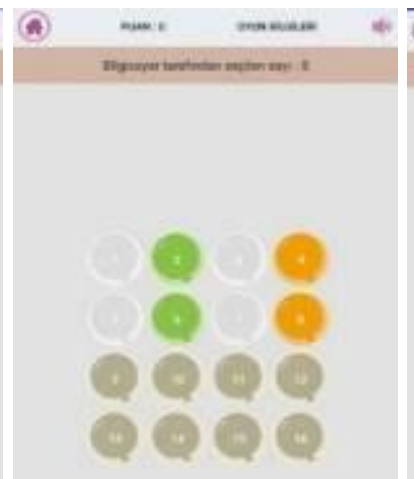

Gameplay

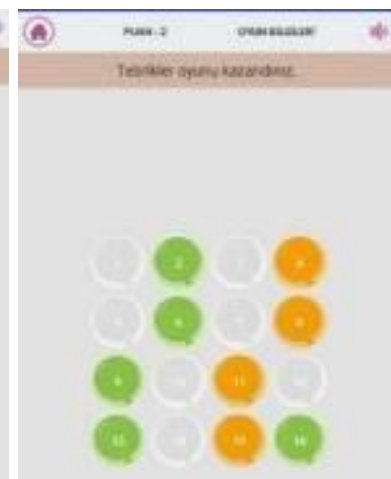

Endgame

Figure 1. Race with numbers game

Race with Numbers game consists of 36 activities, each of the three levels with 12 tasks. Since the constraints and conditions change in each task, the winning numbers also change accordingly. The winning numbers are not random, and they form certain sequences. Therefore, it can be explained with certain models. Choosing each number in 
the winning number sequence in the game equals 1 point. For example, the winning number sequence in the game in Figure 1 is $\{1,4,7,10,13,16\}$. Since the player chose only 2 of these numbers, he earned 2 points at the end of the game. More detailed examinations regarding these explanations are given in Table 1.

Table 1

Application process

\begin{tabular}{cccllc}
\hline Task & Total Balloon & Activated Balloon & Winning Number Sequence & Model & Score \\
\hline 1 & 16 & 2 & $\{1,4,7,10,13,16\}$ & $\mathrm{A}=3 \mathrm{~B}+1$ & 6 \\
2 & 18 & 2 & $\{3,6,9,12,15,18\}$ & $\mathrm{A}=3 \mathrm{~B}$ & 6 \\
3 & 20 & 2 & $\{2,5,8,11,14,17,20\}$ & $\mathrm{A}=3 \mathrm{~B}+2$ & 7 \\
4 & 16 & 3 & $\{4,8,12,16\}$ & $\mathrm{A}=4 \mathrm{~B}$ & 4 \\
5 & 17 & 3 & $\{1,5,9,13,17\}$ & $\mathrm{A}=4 \mathrm{~B}+1$ & 5 \\
6 & 18 & 3 & $\{2,6,10,14,18\}$ & $\mathrm{A}=4 \mathrm{~B}+2$ & 5 \\
7 & 19 & 3 & $\{3,7,11,15,19\}$ & $\mathrm{A}=4 \mathrm{~B}+3$ & 5 \\
8 & 16 & 4 & $\{1,6,11,16\}$ & $\mathrm{A}=5 \mathrm{~B}+1$ & 4 \\
9 & 17 & 4 & $\{2,7,12,17\}$ & $\mathrm{A}=5 \mathrm{~B}+2$ & 4 \\
10 & 18 & 4 & $\{3,8,13,18\}$ & $\mathrm{A}=5 \mathrm{~B}+3$ & 4 \\
11 & 19 & 4 & $\{4,9,14,19\}$ & $\mathrm{A}=5 \mathrm{~B}+4$ & 4 \\
12 & 20 & 4 & $\{5,10,15,20\}$ & $\mathrm{A}=5 \mathrm{~B}$ & 4 \\
\hline
\end{tabular}

During the application process, firstly, the classroom was arranged in a way to encourage group work differently from the traditional seating arrangement. First, the students were allowed to form groups of two. Next, some of these groups (girls) formed the bigger 1st group, while the others (boys) formed the second largest group. The game's application was carried out as a competition of two groups ( 4 or 5 rounds) from the tablets and two large groups on the smartboard. The researcher carried out the application process in line with the stages of TDS (because the mathematics teacher of the classroom is far from the basic philosophy of TDS). Details of this process in terms of both TDS and DGBL are given in Table 2.

Table 2

Application Process

\begin{tabular}{llll}
\hline \multicolumn{1}{c}{ Situations } & \multicolumn{1}{c}{ Definitions } & \multicolumn{1}{c}{ Interaction } & \multicolumn{1}{c}{ DGBL components } \\
\hline Devolution & Understanding the game and its rules & $\mathrm{G} \leftrightarrow \mathrm{T} \leftrightarrow \mathrm{S}$ & $\begin{array}{l}\text { Story, Rules, Goals and } \\
\text { Objectives } \\
\text { Mathematical Stage }\end{array}$ \\
$\begin{array}{l}\text { Challenge, Results, and } \\
\text { Institutionalization } \\
\text { Developing strategy and testing } \\
\text { Discussion, proving, etc. } \\
\text { Moving to the mathematical dimension }\end{array}$ & $\mathrm{G} \leftrightarrow \mathrm{S}$ & $\begin{array}{l}\mathrm{T} \leftrightarrow \mathrm{S} \\
\text { feedback, Interaction }\end{array}$ \\
\hline
\end{tabular}

The interaction in Table 2 means that the teacher mediates the students' understanding of the game at the devolution stage. Thus, the tasks in the game, the rules of the game, and the objective to be achieved in these tasks are transferred to the students by the teacher based on the story used in the game. They interact with the digital game in the mathematical stage and challenge the game's constraints and conditions. In this process, thanks to the results and feedback they get from the game, they discover the game, produce winning strategies in the game, and experience testing and revising them in the game context. However, by discussing these strategies and generalizing the proven strategies, models that make them win the game are obtained. These are expressed mathematically by the teacher by taking them out of the game context during the institutionalization stage. Thus, it is aimed to reach the mathematical knowledge hidden in the digital game presented as an adidactic situation. 


\section{Data collection tools and Analyses}

The research data were collected by recording the application and then the interviews through a video and audio recording device. These recordings were first transferred to the computer environment with the re-listening method. Next, it was analyzed descriptively in line with different stages of TDS. Moreover, the suggested phenomenon was supported by making direct quotations regarding the critical situations for each stage. In the results section, participants were coded based on the classification of group 1 members ( 9 people) as S1, S3,..., S17, group 2 members (7 people) as S2, S4,..., S14, and researcher as $\mathrm{T}$.

\section{Results and Discussion}

In this section, firstly, the actions that students take at different stages of TDS in their digital gaming experience are presented. Second, the mathematical processes they used in these stages were tried to be determined. Finally, reflections on the contribution of the results to the literature are discussed.

\section{Devolution Stage}

This stage started with the teacher introducing the game (such as the rules, tasks, purpose) as given in the following dialogue, explaining the students' and his roles in the game process.

$\mathrm{T}$ : Let me introduce the game to you. The name of our game is Race with Numbers.

S1 : Sir, who is the computer? (game opened on both tablets and smartboard)

$\mathrm{T}$ : Computer is the artificial intelligence, children. You will try to beat him. The game consists of three levels, which are Level 1, Level 2, and Level 3. I opened the game from Level 1. What you see on the screen are balloons. We pop the balloons. You have the same rights as the computer. The game aims to blow the number 16 balloon. My choices are green, the computer's choices are orange.

S1 : Are we going to make that number (balloon number 16) green? (3 seconds later) Ohh, we will make 16th green.

$\mathrm{T} \quad$ : Yes, if you make 16th green, you will win the game. If you pop the biggest numbered balloon on the game screen in other games, you will win the game. For example, if there were 19 balloons on the screen, you should pop the 19th balloon. Do you understand the game?

S1 : Yes.

$\mathrm{T}$ : By the way, you do not ask me if something is right or wrong. You make these kinds of decisions by discussing them on your own. You will play this game this way. Another point is that you always try to think about any possible way to win this game.
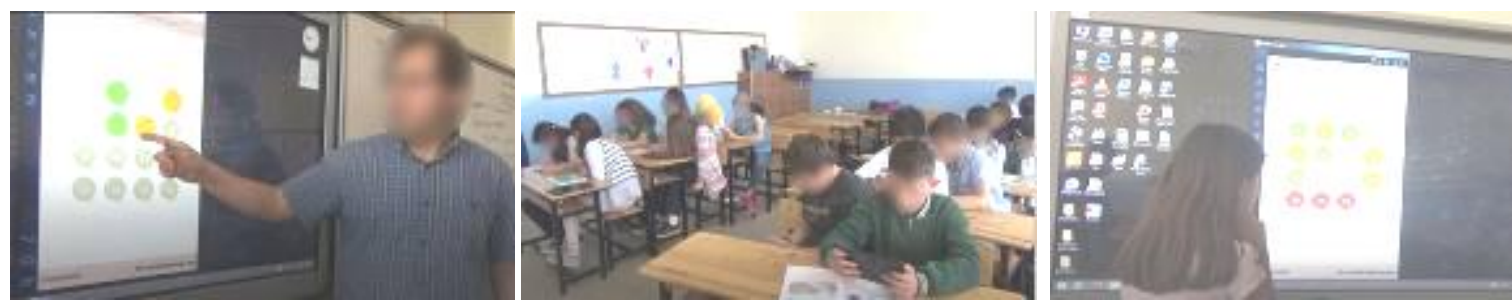

Figure 1. Snapshots from the game in stages of TDS

As can be seen from the dialogues, the teacher made explanations for the game introduction, such as the rules of the game, its purpose, and win-lose cases. These processes were shown through the smartboard (Figure 1). The students played a number 
of games randomly from their own tablets. It is understood here that the students fully understand the game. This stage lasted about 5 minutes.

\section{Mathematical stage}

The mathematical situation started with the students playing the game on their tablets or mobile phones for a certain time. At least, 5 games were played during this period.

In these games, students started to challenge the game's constraints and conditions as they face the position of winning and losing. Although they had some implicit inferences about the game (indicative of winning status), they did not share this among themselves. It can be stated that students generally act individually in this process. A moment from this process is presented in Figure 1. Students' behaviors indicated that they won with gestures and gestures, jumping up from where they are, and exclamation such as "I won, sir!" and "Yes, hurrah!" are noteworthy in this case. However, no sharing was made showing how students won the game and why they thought the winning strategy was correct in this process. On the other hand, it was observed that students lost in some games. Such situations are considered important for students to make informed decisions. The dialogue below reflects the students' perplexity at not understanding why they lost the game.

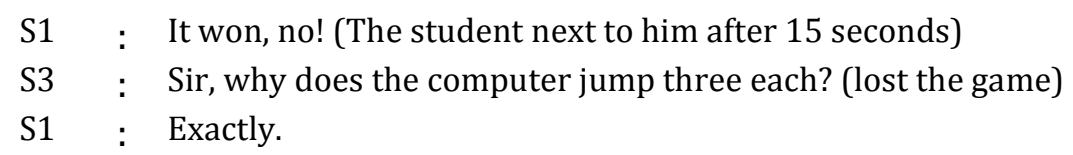

The emergence of such a situation is of critical importance in terms of continuing the game process. If the students were successful in using the inferences they obtained at the easy level of the game in the later levels of the game, they would not want to play this game anymore. Therefore, the sense of uncertainty and curiosity that kept the replay of the game alive would have disappeared. In other words, although it is observed that students adapt to the game and focus on the idea of winning, it reveals that the implicit strategies they find through trial and error in the first tasks do not work in more advanced tasks.

After the game play in doubles, the class was divided into two large groups; then, the group game was started. Making such a change can be explained as the dissemination and verification (approval or rejection) of the knowledge obtained in groups of two implicitly, first within the group and then among the groups. Besides, this approach can reveal mathematical processes such as transfer, reasoning, problem solving and association, argument, and proofing.

The group game started to be played on the smartboard. Although the groups were not intended to be separated, especially as boys and girls, this was not intervened at the students' request (normally mixed and equal). When the students won the game, they received the points specified in Table 1 at the end of the game each time they chose the winning numbers. Additionally, it was stated that the winning group would receive 1 point in games played on the smartboard in group games. Part of the game process performed between the groups (12 games at easy level) is given in Table 3.

Table 3

Games that take place between groups (Only including level 1 games)

\begin{tabular}{cccccccc}
\hline Number & $\begin{array}{c}\text { Total } \\
\text { Balloon }\end{array}$ & $\begin{array}{c}\text { Activated } \\
\text { Balloon }\end{array}$ & Gaming process & Student & Win/Loss & Group & Score \\
\hline 1 & 16 & 2 & $\{1,3,5,9,13,16\}$ & S1 & 1 & G1 & 2 \\
2 & 18 & 2 & $\{1,4,6,10,12,15,18\}$ & S2 & 1 & G2 & 4 \\
3 & 20 & 2 & $\{1,5,7,10,13,15,18\}$ & S3 & 0 & G1 & 1 \\
4 & 20 & 2 & $\{2,5,8,10,13,16,19\}$ & S4 & 0 & G2 & 3 \\
\hline
\end{tabular}


Table 3 (continued)

\begin{tabular}{|c|c|c|c|c|c|c|c|}
\hline Number & $\begin{array}{c}\text { Total } \\
\text { Balloon }\end{array}$ & $\begin{array}{c}\text { Activated } \\
\text { Balloon }\end{array}$ & Gaming process & Student & Win/Loss & Group & Score \\
\hline 5 & 20 & 2 & $\{1,5,9,13,17,20\}$ & S5 & 1 & G1 & 3 \\
\hline 6 & 16 & 3 & $\{1,6,11,13\}$ & S6 & 0 & G2 & 0 \\
\hline 7 & 16 & 3 & $\{3,8,13\}$ & $\mathrm{S} 1$ & 0 & G1 & 1 \\
\hline 8 & 16 & 3 & $\{3,7,9,15\}$ & $\mathrm{S} 2$ & 0 & $\mathrm{G} 2$ & 0 \\
\hline 9 & 16 & 3 & $\{1,6,11,13\}$ & S7 & 0 & G1 & 0 \\
\hline 10 & 16 & 3 & $\{2,7,12,16\}$ & S8 & 1 & $\mathrm{G} 2$ & 2 \\
\hline 11 & 17 & 3 & $\{2,7,10,15\}$ & S9 & 0 & G1 & 0 \\
\hline 12 & 17 & 3 & $\{3,7,12,14\}$ & S10 & 0 & G2 & 0 \\
\hline 13 & 17 & 3 & $\{1,7,11,14\}$ & S11 & 0 & G1 & 1 \\
\hline 14 & 17 & 3 & $\{1,5,8,10,14\}$ & S12 & 0 & G2 & 2 \\
\hline 15 & 17 & 3 & $\{2,6,10,14\}$ & S13 & 0 & G1 & 0 \\
\hline 16 & 17 & 3 & $\{1,5,9,11,14\}$ & S14 & 0 & $\mathrm{G} 2$ & 3 \\
\hline 17 & 18 & 3 & $\{3,7,10,14,18\}$ & S15 & 1 & G1 & 3 \\
\hline 18 & 19 & 3 & $\{1,3,6,9,15,19\}$ & $\mathrm{S} 2$ & 1 & $\mathrm{G} 2$ & 3 \\
\hline 19 & 16 & 4 & $\{4,9,12\}$ & S17 & 0 & G1 & 0 \\
\hline 20 & 16 & 4 & $\{4,9,13\}$ & S4 & 0 & $\mathrm{G} 2$ & 0 \\
\hline 21 & 16 & 4 & $\{3,8,12\}$ & S1 & 0 & G1 & 0 \\
\hline 22 & 16 & 4 & $\{1,6,8,15\}$ & S6 & 0 & G2 & 2 \\
\hline 23 & 16 & 4 & $\{3,5,9,12\}$ & S3 & 0 & G1 & 0 \\
\hline 24 & 16 & 4 & $\{1,6,11,16\}$ & S8 & 1 & G2 & 4 \\
\hline 25 & 17 & 4 & $\{2,6,12,17\}$ & S11 & 1 & G1 & 3 \\
\hline 26 & 18 & 4 & $\{2,7,12,14\}$ & S10 & 0 & G2 & 0 \\
\hline 27 & 18 & 4 & $\{3,7,13,18\}$ & S19 & 1 & G1 & 3 \\
\hline 28 & 19 & 4 & $\{1,5,10,18\}$ & $\mathrm{S} 12$ & 0 & $\mathrm{G} 2$ & 0 \\
\hline 29 & 19 & 4 & $\{2,6,10,18\}$ & S5 & 0 & G1 & 0 \\
\hline 30 & 19 & 4 & $\{2,6,12,17\}$ & S14 & 0 & G2 & 0 \\
\hline 31 & 19 & 4 & $\{3,7,14,19$ & S9 & 1 & G1 & 2 \\
\hline 32 & 20 & 4 & $\{2,7,10,15,20\}$ & S2 & 1 & G2 & 3 \\
\hline
\end{tabular}

As can be seen from this dialogue, it is observed that S2 makes her choices by reasoning. In this context, the student stated why she did not choose 13 and 14 after choosing 15 as leaving the numbers 16,17 , and 18 to the computer in the next move. Therefore, S2 coded student stated that no matter which computer she chooses, she could win the game by choosing 19 when it was her turn. In this process, it is observed that the student makes her decisions about choosing balloons by logical inference. Therefore, there is intellectual reasoning in this step. On the other hand, it can be stated that the S1 coded student who wanted to be involved in the game process was acting against the didactic contract because an intervention to the student's game on the smartboard would undermine her thinking process and the opportunity to make reasoning would be blocked by not being exposed to a situation she could overcome. Since the teacher did not allow the $\mathrm{S} 1$ coded student to intervene in the game, such an obstacle did not arise. After these games, the teacher made the following explanations to reshape the student interaction in the environment to reveal winning strategies in the game.

$\mathrm{T}$ : Yes, now ... I want you to give a hypothesis... For example, if I play 15, I win. We will also score the hypotheses. If the class confirms a group's hypothesis, the group that submitted it will receive 1 point. If one group refutes the other group's hypothesis, the refuting group will receive 3 points. So, it is more valuable to refute a hypothesis.

In the next period, the environment was organized again by the teacher so that the students make attempts to reach the knowledge hidden behind the game. They were asked 
what the winning strategy/strategies could be in the game in this context. They were asked to discuss the approval of these strategies by the students. It is thought that this approach can serve in solving the problem consisting of many tasks hidden behind the game in the transmission and dissemination of knowledge among students. Table 4 shows the students' hypotheses in different tasks in these processes and the verification process in the game context.

Table 4.

The hypotheses presented by the students and the process of experiencing

\begin{tabular}{|c|c|c|c|c|}
\hline Number & $\begin{array}{c}\text { Task } \\
\text { (Hard level) }\end{array}$ & & Gaming Process & Verification \\
\hline \multirow[t]{2}{*}{1} & Task 8 & S2 & We have a strategy. & \multirow[b]{2}{*}{$\begin{array}{l}\text { Approval } \\
\text { (class) }\end{array}$} \\
\hline & & S8 & : (Wins the game) Teacher, S2 should tell us (in-group & \\
\hline 2 & Task 2 & S6 & $\begin{array}{l}\text { : I will go two by two. (Loses the game) Oh, no. It } \\
\text { (computer) won. } \\
\text { : Exactly, it wins always (in-group discussion) }\end{array}$ & $\begin{array}{l}\text { Refusal } \\
\text { (in-group) }\end{array}$ \\
\hline 3 & Task 2 & $\begin{array}{l}\text { S6 } \\
\text { S4 } \\
\text { S2 }\end{array}$ & $\begin{array}{l}: \text { Go by even and odd. } \\
: \text { I also think so. } \\
: \text { Just a minute. I need to try that. No, it did not work (in- } \\
\text { group discussion) }\end{array}$ & $\begin{array}{l}\text { Refusal } \\
\text { (in-group) }\end{array}$ \\
\hline 4 & Task 12 & S2 & $\begin{array}{l}\text { I tried to get } 15 \text {. That's why I said } 2,7,10 \text {. There are } \\
\text { already } 4 \text { moves. It would go either } 14,13,12 \text {, or } 11 \text {. I } \\
\text { did that to block the } 15 \text { th. I pressed } 15 \text { (chooses). Then } \\
\text { it already has } 4 \text { moves (can choose } 16,17,18 \text {, and } 19) \text {. } \\
\text { It comes to } 19.20 \text { (I chose } 20 \text { ) }\end{array}$ & $\begin{array}{l}\text { Approval } \\
\text { (class) }\end{array}$ \\
\hline \multirow[t]{5}{*}{5} & Task 3 & S6 & $\begin{array}{l}\text { If it plays by two each (number of activated balloons), I } \\
\text { should choose } 3 \text { less, if by three each, I should choose } 4 \\
\text { less. }\end{array}$ & \multirow{5}{*}{$\begin{array}{l}\text { Approval } \\
\text { (class) }\end{array}$} \\
\hline & & S2 & $\begin{array}{l}\text { For example, } 20 \text { minus } 3 \text { is } 17 \text {. If we reach } 17 \text {, it has } 2 \\
\text { moves (computer). Either it will go to } 18 \text { or } 19 \text {. If it } \\
\text { goes to } 18 \text {, we will get } 20 \text {. If it goes to } 19 \text {, we will get } \\
20 \text {. (However, at the end of the game, the computer } \\
\text { reached } 17 \text { before the students) }\end{array}$ & \\
\hline & & S1 & I accept this, but it cannot reach 17 . & \\
\hline & & S4 & S6, we should not get it to choose 17 . & \\
\hline & & $\mathrm{T}$ & Discuss some more in the group. & \\
\hline \multirow[t]{3}{*}{6} & Task 3 & S1 & My hypothesis is to reach 14 . & \multirow{3}{*}{$\begin{array}{l}\text { Approval } \\
\text { (class) }\end{array}$} \\
\hline & & S2 & $\begin{array}{l}\text { Can I say something, teacher? (allowed) If it reaches } 14 \\
\text { already, it will jump directly to } 17 \text {. That was also our } \\
\text { hypothesis. } \\
\text { (S2 answers) But you said } 17 \text {. This is something } \\
\text { different... (S1 questions). You would reach 14, what } \\
\text { happened? }\end{array}$ & \\
\hline & & S1 & $\begin{array}{l}\text { No, it did not work? Sir, if it had chosen } 10 . \text { I would } \\
\text { directly choose } 11 .\end{array}$ & \\
\hline 7 & Task 3 & S8 & $\begin{array}{l}\text { Sir, we said we should come to } 17 \text { before } 20 \text {. (in-group } \\
\text { decision) We had to go } 3 \text { each. So, we thought to come } \\
\text { to } 17 . \\
\text { (Shows by the hand saying "If we go back like this") } \\
\text { We started from } 2 \text {. } \\
\text { We reached } 20 \text { when we started from } 2 \text { and went in } 3 \\
\text { each (Pattern) }\end{array}$ & $\begin{array}{l}\text { Approval } \\
\text { (class) }\end{array}$ \\
\hline
\end{tabular}


In Table 4, it is possible to divide the strategies (or hypotheses) developed during the game process into three. Those in the first category (e.g., the first number in Table 4) were won in the game context and were immediately approved. The second category (e.g., the second number in Table 4) is strategies that are generally rejected in group discussions. Thanks to the intellectual reasoning in the third category (for example, fifth and sixth numbers in Table 4), the strategies that the computer wins in the game and whose accuracy was logically discovered became the knowledge of students. Although these result in a losing position due to struggle at the hard level in the game (or because the algorithm is activated in early moves), students are aware that they can reach the winning position by developing and revising these strategies. Based on this fact, the last strategy given in Table 4 is a consistent synthesis for the emergence of the game's winning strategy by analyzing the previous ones.

Thanks to this strategy, a local solution emerged regarding task 1 to task 3 (see Table 1). While other tasks could be specified similarly, it could have been provided in time for them to emerge and students to discover local solutions for these tasks. However, since the implementation phase was carried out in a limited time, the teacher decided to move to the institutionalization stage after the local solution. The mathematical situation stage lasted around 65 minutes.

\section{Institutionalization stage}

At this stage, the teacher generalized the students' solution and presented a general strategy to be used in all tasks in the game. He also pragmatically demonstrated how this strategy works for different tasks in the context of the game. Dialogues regarding these explanations are given in the following paragraph.

\begin{tabular}{|c|c|c|}
\hline Students & & $\begin{array}{l}\text { It is possible to always win in this game. S8 showed one of them. I will show you the } \\
\text { others too. How many balloons are activated? (For Task } 4 \text {. The students shout 3.) } \\
\text { Add } 1 \text { to this? } \\
\text { Makes } 4\end{array}$ \\
\hline $\mathrm{T}$ & & $\begin{array}{l}\text { If you count back four by four from the last balloon, you will always find th } \\
\text { winning numbers. }\end{array}$ \\
\hline S6 & & Sir, we told this. \\
\hline S2 & & Same as ours. \\
\hline $\mathrm{T}$ & & $\begin{array}{l}\text { You said, but it wasn't for all... The general strategy for winning was this. } 1 \text { plus } 0 \\
\text { the balloons activated will be your divider, okay? But the number is also importan } \\
\text { (points to the largest numbered balloon). What is the remainder of the last number } \\
\text { divided by } 1 \text { plus the activated number? You have to choose the numbers with tha } \\
\text { property, okay? This leads us to division with remainders as a mathematica } \\
\text { structure. See, let's do it. (for task 11) The number of balloons activated is } 4 \text {. Plus } 1 \\
\text { is } 5 \text { (students confirm). What is the remainder of } 19 \text { divided by } 5 \text { ? It is } 4 \text {. Look, if } \\
\text { choose } 4 \text {, then plus } 5 \text { is } 9 \text {, and then plus } 5 \text { is } 14 \text {, and finally } 19 \text {, I win. (Wins the } \\
\text { game) }\end{array}$ \\
\hline
\end{tabular}

As can be seen from the dialogue, the teacher showed how it could be used by adapting it to different tasks' constraints and conditions after referring to the students' strategy. Then, he generalized it to a mathematical dimension. In this context, he explained that the mathematical structure hidden in the game is the division with remainders (Euclidean division). He also tested the division with remainders in one final task (task 11) and demonstrated the overall solution's accuracy. This stage lasted 5 minutes.

In the literature focus, the comments regarding the study results are given below under two subheadings. 
Introduction of mathematical knowledge through digital games designed according to TDS

This study showed that digital games could be used as an effective tool in preparing a student-centered environment and reaching mathematical knowledge in this environment. Based on this context, the concept of the division with remainders was introduced to 6thgrade students through a digital game. Devlin (2021) emphasizes that a limited number of digital games encourage conceptual understanding. The study, in which the conceptual meaning of the concept of the division with remainders is presented with a digital game, is important in terms of reflecting an application of this. This result largely coincides with the results obtained from studies on the creation of student-centered environments of digital games (Navarrete, 2013) and the use of digital games as a tool for educational purposes (Sousa \& Costa, 2018).

It was also determined that the digital game allows students to act independently in different stages of TDS. In this direction, it was observed that they understood the rules and purpose of the game and how winning or losing happened during the devolution stage. The mathematical situation includes discovering the digital game and developing strategies regarding the knowledge hidden in the game, testing them, and constantly revising their strategies accordingly. In this process, limiting the teacher's interventions and their efforts to reach the knowledge behind the game from the inferences they derive from the digital game are indicators of supporting student-centered ideas. It can be stated that the didactic contract between teacher and students (Brousseau, 2002) plays a key role in keeping the student-centered approach alive in this process.

On the other hand, Brousseau (2002) stated that students might experience difficulties from time to time in the mathematical situation stage. It is stated that such blockages can be resolved in well-designed technology-based learning environments such as digital games (Gök et al., 2020). The reason for this can be explained by the availability of feedback from multiple sources (such as visual, auditory, and numeric), not just one source, in learning situations where technological tools are used.

In this study, it was determined that 6th-grade students could produce limited solutions to the tasks presented in the context of digital games. It is seen that the teacher explained the general solution during the institutionalization stage. Besides, it was stated by the teacher that the mathematical concept behind the game in the institutionalization stage was the division with remainders. In the games developed within the framework of TDS, it is seen that although the participants mostly discover the mathematical situation behind the game in the context of the game, this does not occur in a formal sense (Brousseau, 2002; Gök et al., 2020). Considering the formation process of mathematical concepts, it can be stated that this is difficult for middle school students. In this sense, the results obtained in this study are similar to those suggested in the literature.

\section{Contribution of the digital game and student interaction to mathematical processes}

In this study, a problem situation presented as hidden in the digital game is divided into many tasks. The solution of these tasks includes limited solutions to the problem situation, and the solution is obtained by synthesizing these tasks. Therefore, it can be said that well-designed digital games could support middle school students' problem-solving skills. Kiili (2007) expressed that digital games enable students to use processes such as developing strategies, experimenting, interpreting, and adapting them to solve problems, and this experiential approach provides evidence for students to become problem solvers. In another study, Lowrie ( $\underline{2005}$ ) observed that digital games encourage productivity in problem-solving and motivate players to solve problems as a part of the game. This study determined that students developed many strategies in games for tasks in the digital game, 
proved them in in-group discussions and large-class discussions, spread the implicit models they obtained, and transformed them into classroom knowledge. These results indicate that students use a mathematical processes strategy in their problem-solving attempts in the context of digital games.

Tonéis (2017) pointed out that environments designed around digital games can be used to access mathematical knowledge through reasoning. Similar to this result, this study shows that feedback from digital games plays an important role in accessing the mathematical knowledge hidden in digital games by passing through the reasoning filter. In this regard, mathematical reasoning encourages the cycle of proof of technology in the form of discovery, assumption, test/control, and proof that supports each other to reveal knowledge in the digital game (Cullen et al., 2020). More generally, it can be asserted that digital games improve students' social skills (such as communication, cooperation, negotiation, and taking responsibility) and higher-order thinking skills (such as problemsolving and critical reasoning) (Shute \& Ke, 2012).

These results indicate that digital games have the potential to develop students' skills. To this end, Shute and Ke (2012) claimed that new ideas were needed for students to develop 21st-century skills and digital games could be used accordingly. In the same study, it was emphasized that they motivate students and facilitate the presentation of complex academic content and the learning of 21st-century skills.

\section{Conclusion}

This study showed that digital games designed according to TDS could be used as an effective tool in preparing a student-centered environment and reaching mathematical knowledge in this environment. Besides, the mentioned environment provided a regulatory function regarding students' and teacher's roles in the process of digital game implementation.

In this research, strong evidence was obtained that middle school students used mathematical process skills (such as problem-solving, reasoning, proving, and transfer) in the DGBL environment, which was designed with a didactic perspective. In this context, it was determined that mathematical process skills emerged in the mathematical situation where students' interaction with digital games was concentrated.

The results obtained in this study reflect the students' limited experience with a digital game. Although strong evidence of the results was presented, it is believed that longer-term studies and reviews of the extent to which digital games affect and support mathematical processes could open new doors in the literature. By integrating didactic theories and DGBL, a theoretical framework for teaching mathematical knowledge to students in a meaningful way through digital games can be created.

\section{Acknowledgment}

The authors would like to thank Zeve secondary school administration for their help with the study and the 6th-grade students who participated in the study.

\section{Bibliography}

Arsac, G., Germain, G., \& Mante, M. (1991). Problèmeouvertet situation problème (Première édition 1988). Lyon: IREM de Lyon. https://publimath.univirem.fr/biblio/ILY91002.htm 
Brousseau, G. (2002). Theory of didactical situations in mathematics. Dordrecht: Kluwer Academic Publishers.

Brousseau, G., \& Warfield, V. (2014). Didactic situations in Mathematics education. In S. Lerman (Ed.), Encyclopedia of Mathematics Education (pp. 163-170). Dordrecht: Springer Netherlands. https://doi.org/10.1007/978-3-030-15789-0 47

Chen, Z. H., Liao, C. C., Cheng, H. N., Yeh, C. Y., \& Chan, T. W. (2012). Influence of game quests on pupils' enjoyment and goal-pursuing in math learning. Journal of Educational Technology \& Society, 15(2),
https://www.jstor.org/stable/10.2307/jeductechsoci.15.2.317

317-327.

Cullen, C. J., Hertel, J. T., \& Nickels, M. (2020). The roles of technology in mathematics education. The Educational Forum, 84(2), 166178. https://doi.org/10.1080/00131725.2020.1698683

Dahl, B. (2018). What is the problem in problem-based learning in higher education mathematics. European Journal of Engineering Education, 43:1, 112-125. https://doi.org/10.1080/03043797.2017.1320354

Devlin, K. (2021). Creating an educational tool that uses interactive representations to provide a new approach to mathematics learning. ZDM-Mathematics Education, 1-11. https://doi.org/10.1007/s11858-021-01235-4

Gee, J. P. (2007). What video games have to teach us about learning and literacy. Palgrave Macmillan.

Gök, M., İnan, M., \& Akbayır, K. (2020). Sınıf öğretmeni adaylarına Öklid bölmesinin bir mobil oyunla tanitılması. Cumhuriyet International Journal of Education, 9(1), 219242. http://dx.doi.org/10.30703/cije.560761

Hung, C. M., Huang, I., \& Hwang, G. J. (2014). Effects of digital game-based learning on students' self-efficacy, motivation, anxiety, and achievements in learning mathematics. Journal of Computers in Education, 1, 151-166. https://doi.org/10.1007/s40692-014-0008-8

Iivari, N., Sharma, S., \& Ventä-Olkkonen, L. (2020). Digital transformation of everyday lifeHow COVID-19 pandemic transformed the basic education of the young generation and why information management research should care? International Journal of Information

Management, p. 102183. https://doi.org/10.1016/j.ijinfomgt.2020.102183

Jong, M. S. Y., Shang, J., Lee, F.-L., \& Lee, J. H. M. (2008). Harnessing computer games in education. Journal of Distance Education Technologies, 6(1),1-9. https://doi.org/10.4018/jdet.2008010101

Ke, F., \& Grabowski, B. (2007). Game playing for mathematics learning: Cooperative or not? British Journal of Educational Technology, 38(2), 249-259. https://doi.org/10.1111/i.1467-8535.2006.00593.x

Kiili, K. (2005). Digital game-based learning: Towards an experiential gaming model. The Internet and higher education, 8(1),

13-24. https://doi.org/10.1016/j.iheduc.2004.12.001 
Kiili, K. (2007). Foundation for problem-based gaming. British Journal of Educational Technology, 38 (3), 394-404. https://doi.org/10.1111/j.1467-8535.2007.00704.x

Laborde, C. (2007). Towards theoretical foundations of mathematics education. ZDM Mathematics Education, 39, 137-144. https://doi.org/10.1007/s11858-006-0015-y

Lowrie, T.,\& Jorgensen, R. (2015). Digital games and learning: What's new is already old?', in Lowrie, T. and Jorgensen, R. (eds) Digital games and mathematics learning potential, promises and pitfalls (pp. 1-9). The Netherlands: Springer. https://doi.org/10.1007/978-94-017-9517-3 1

Lowrie, T. (2005). Problem solving in technology rich contexts: Mathematics sense making in out-of-school environments. The Journal of Mathematical Behavior, 24(3-4), 275286. https://doi.org/10.1016/j.jmathb.2005.09.008

Macfarlane, A. (2020). Anthropology and the third information revolution. Visual Anthropology, 33(3), 197-211. https://doi.org/10.1080/08949468.2020.1746615

Mayer, R. E., \& Johnson, C. I. (2010). Adding instructional features that promote learning in a game-like environment. Journal of Educational Computing Research, 42(3), 241265. http://dx.doi.org/10.2190/EC.42.3.a.

Merriam, S. B. (2013). Nitel vaka çalışması (Çev: E. Karadağ). S. Turan (Ed.), Nitel araştırma desen ve uygulama için bir rehber içinde (3 ed.). Ankara: Nobel.

National Council of Teachers of Mathematics [NCTM]. (2000). Principles and standards for school mathematics. VA: Reston.

Navarrete, C. C. (2013). Creative thinking in digital game design and development: A case study. Computers \& Education, 69,

320-331. https://doi.org/10.1016/j.compedu.2013.07.025

Nickels, M., \& Cullen, C. J. (2017). Mathematical thinking and learning through robotics play for children with critical illness: The case of Amelia.Journal for Research in Mathematics Education, 48(1),

22-77. https://doi.org/10.5951/jresematheduc.48.1.0022

Prensky, M. (2001). Digital game-based learning. New York: McGraw-Hill.

Radović, S., Marić, M., \& Passey, D. (2019). Technology enhancing mathematics learning behaviours: Shifting learning goals from "producing the right answer" to "understanding how to address current and future mathematical challenges". Education and Information Technologies, 24(1), 103-126. https://doi.org/10.1007/s10639-018-9763-x

Shute, V. J., \& Ke, F. (2012). Games, learning, and assessment. In D. Ifenthaler, D. Eseryel, \& $\mathrm{X}$. Ge (Eds.), Assessment in game-based learning: Foundations, innovations, and perspectives (pp. 43-58). New York, NY: Springer. https://doi.org/10.1007/978-14614-3546-4 4

Sousa, C., \& Costa, C. (2018). Videogames as a Learning Tool: Measuring the Efficacy of Game-Based Learning Interventions. Revista Lusófona de Educação, 40, 199-210. https://doi.org/ 10.24140/issn.1645-7250.rle40.13 
Tonéis, C. N. (2017). The act of playing and the logical and mathematical reasoning in digital games: The mathematical experience in the digital games. Entertainment Computing, 18, 93-102. https://doi.org/10.1016/j.entcom.2016.10.001

Van Eck, R. (2006). Digital game based learning: It is not just the digital natives who are restless. Educause Review, 41, 16-30.

Warfield, V., M. (2014). Invitationto didactique. New York: Springer.

Yong, S. T., Karjanto, N., Gates, P., Chan, T. Y. A., \& Khin, T. M. (2020). Let us rethink how to teach mathematics using gaming principles. International Journal of Mathematical Education in Science and Technology, 1-20. https://doi.org/10.1080/0020739X.2020.1744754 